\title{
Role of Documentation and Legal Information Network (JDIH) Efforts in Fulfillment of Human Rights
}

\begin{abstract}
Dewi Sukmaningsih ${ }^{1}$
Abstract. Indonesia is a country of law, and one of the characteristics of a state of law is the guarantee and protection of human rights, one of which is the right to obtain information, including the legal information that is information about the legislation both national and local. The principle of fiction (fictie) law states that any person considered to determine the existence of a legislation after its enactment, the ignorance of the people on the legislation, can not be excused. To that end, legislation information should be easily accessible. Issuance of Presidential Decree No. 33 of 2012 on Information and Documentation Network of National Law (JDIHN) isin order to fulfill the right to obtain legal information, especially information legislation. Management of Legal Documentation and Information Network by utilizing information and communication technology (ICT) makes legal information can be accessed quickly, easily, complete and accurate, thereby supporting the fulfillment of human rights, namely the right to obtain legal information properly.

Keywords: Documentation and Legal Information Network, Efforts, Fulfillment, Human Rights
\end{abstract}

\section{Introduction}

Based on the Constitution of the Republic of Indonesia of 1945 pursuant to Part I Article 1 (3) mentioned Indonesia is a State of Law. In the concept of State of Law, the existence of legislation is one of the fundamental elements for the implementation of state government based on law, Fredrich Julius Stahl suggests the characteristics of a state of law is as follows:

- The protection of human rights;

- Separation or division of powers to guarantee the human rights that (Trias Politica);

- Government by regulations;

- Judicial Administration; ${ }^{2}$

So we can conclude, one feature of a state of law is the guarantee of human rights (HAM) including the right to information law, because Indonesia is a country of law where every operation of government based on laws and regulations, the people are entitled to access to legal information related with legislation that has been established and promulgated.

The principle of fiction (fictie) law states, everyone is considered to determine the existence of a legislation that has been enacted. In other words, a legal fiction to assume everyone knows the law (presumption iures de iure). Ignorance of the people on the legislation, thus can not be forgiven (ignorantia jusrist non excusat).

\footnotetext{
${ }^{1}$ Student Masters (S-2) of Law Faculty of Law UNISSULA Semarang email dewiadams99@gmail.com

2 Arif Budiman, 1982, Bentuk Negara dan Pemerataan Hasil-hasil Pembangunan, Prisma No.7, Jakarta,p.4-6
} 
It does not seem fair that people deemed to know all the laws and all the consequences of the offense but does not have the right to obtain information relevant legal regulations. For that reason in the state constitution the right to obtain information guaranteed in Article 28 letter f:"Everyone has the right to communicate and obtain information to develop personal and social environment, and the right to seek, obtain, possess, store, process and convey information by using all available channels". ${ }^{3}$ Right to information is guaranteed in Act No. 14 of 2008 on Public Disclosure of Article 4 paragraph (1). In Act No. 39 of 1999 on Human Rights, the right to communicate and obtain information included in the right to develop themselves under Article 14. Literally the meaning of human rights is a fundamental right, so their presence is a must, be inviolable, even to be protected. Respected and defended from all sorts of threats, obstacles and interference from other humans. ${ }^{4}$

Issuance of Presidential Decree No. 33 of 2012 on Information and Documentation Network of National Law (JDIHN) is in order to fulfill the right to information law, especially information legislation. Both legislation and the Regional Center.

To the authors wanted to know, "How Role Network Documentation and Legal Information in fulfilling human rights?"

\section{Results And Discussion}

In accordance with the Presidential Decree No. 33 of 2012, the Network of Documentation and Information of the National Law (JDIHN) the joint utilization of container on material legal documents in an orderly, integrated and sustainable as well as a means of legal information service delivery of complete, accurate, easy, and fast. Documentation and Information Network National Law (JDIHN) cooperation is directed to utilize material legal documents, especially legislation and other legal instruments for the realization of a network of documentation and information of national law. This is because the laws and other legal instruments published at any time in accordance with the pattern of the ever-evolving government policy. Therefore, the implementation of document management laws should be held on an ongoing basis between the Center JDIHN members and between members. In this case JDIHN Center is BPHN Ministry of Law and Human Rights,

At first, the search for legal information is done manually, that is, for those who need the information can directly come to the service center of legal information library of legal documents, and sometimes the results are not satisfactory because legal information sought is not available and it takes a long time and less practical.

The rapid development of technology and information to change the paradigm of governance to practice Electronic Government (E-Government). E-Government is the use of technology and information and communication in governance by government institutions to improve performance and the relationship between government and other parties, including the public. The use of this information technology relationships and expand public access to legal information so that the information included

\footnotetext{
${ }^{3}$ Second Amendment Amendment of 1945 Constitution

${ }^{4}$ Harun Pudjiarto, 1999, Hak Asasi Manusia, Kajian Filosofis dan Implementasinya dalam Hukum Pidana Indonesia, Andi Offset, Yogyakarta, p. 25
} 
increased government accountability. ${ }^{5}$ One implementation of E-Government is to build portals or websites on Government Agencies. Various regulations have been issued as the legal foundation of a web-based legal information systems and Internet networks.

With the increasingly massive use of Information and Communication Technology (ICT) in search of information, including information about the legislation, the use of ICT in the Management JDIH is absolutely necessary, it is in order to improve services to the public above the needs of documentation and legal information easily and quickly. One application of ICT is a global Internet network. Through this network can be said to negate the distance and limit the dissemination of and access to information. ${ }^{6}$ So that the law can be direct information seekers to easily access information legislation through websites JDIH already built.

Dissemination of information that is easily accessible with a one-click method has become the everyday people anywhere and anytime even have become trends of Internet usage in Indonesia. ${ }^{7}$ In Article 10, paragraph (2) b of Presidential Regulation No. 33 Of 2012 JDIHN Member mentioned in his duties performs functions based legal information system development of information and communication technologies that can be integrated with JDIHN Center website. This means that there is an obligation both for the Center and member JDIH to build potal or JDIH website as a medium of information dissemination law, especially laws and regulations. The Website JDIHN standardization is one JDIH management standard which is regulated by the Ministry of Justice No. 02 of 2013 on the Standardization of Technical Documentation and Information Management Law. In essence, the website is a communication tool that provides information to the public through the use of Internet technology.

Utilization of ICT in JDIH also in the framework of the Public Service in the era of openness, in accordance with the principles contained in the public service, namely transparency, that are open, easy, and accessible to all those in need and provided adequately and easily understandable ${ }^{8}$

The use of the website as a medium for the dissemination of information laws, especially the legislation is in line with the principle of good governance processes that create transparency. Transparency means opening up access for all parties interested in any related information such as rules and regulations, and policies with minimal cost. transparency as providing information to the public about government and guaranteed the ease in obtaining information that is accurate and adequate, that transparency does not just provide information about governance, but it should be accompanied by a convenience for people to obtain information. ${ }^{9}$ The purpose of

\footnotetext{
5 Karina Maharani, 10 Agustus 2010, "Pelaksanaan Sistem Informasi Manajemen Terpadu Di Biro Perencanaan Kantor Kementerian Regara Riset Teknologi", http://elib.unikom.ac.id/gdl.php?mod=browse\&op=read\&id=jbptunikompp-gdl-karinamaha21144\&q=sistem\%20pelayanan\%20informasi, Accessed on 24 September 2018

${ }^{6}$ Blasius Sudarsono, 2009, Pustakawan Cinta dan Teknologi, ISIPII, Jakarta, p. 37

${ }^{7}$ Testiani Makmur,2015, Perpustakaan Era Keterbukaan Informasi Publik, Graha Ilmu, Yogyakarta, p. 3

${ }^{8}$ Nomensen Sinamo, 2005, Hukum Administrasi Negara, Jala Permata Aksara, Jakarta, p..81

9 Agus Dwiyanto, 2003, Mewujudkan Good Governance Melayani Public, Gajdah Mada University, Yogyakarta, p.80
} 
transparency is to build mutual trust between the government and the public that the government must provide accurate information to the public in need, especially the reliable information related to legal issues, regulations, and the results achieved in the governance process. Mechanism that enables public access to relevant information, the rules governing the obligation of local governments to provide information to the public, and fostering a culture in the community to scrutinize the resultant policies of local governments. With regulated of Act No. 14 of 2008 on Public Information, is expected to create transparency is the character of good governance. With this transparency,

Integration policies of all member JDIHN website to website JDIHN Center aims to create a complete legal information services, quickly and easily in a single portal / website JDIHN Center (Single Online Portal), well-informed legislation and regional centers. Integration Discourse website starting in 2015, which was disseminated in the activities of APEC Workshop on Implementation of Application Integration Website JDIHN in Batam, on 25-26 September 2015, and is expected within a period of 3 years from 2015 all member JDIHN website is integrated with JDIHN Center website. On the activities of Capacity Building for Managing Single Online Portal for Regulatory Information in Lombok on 25-26 July 2018, the Ministry of Justice and Human Rights BPHN has four priority activities, including the acceleration of the membership, improvement of systems / applications, ${ }^{10}$, All of them are good efforts website development JDIH, Policy Integration entire website member JDIH to the Center's website JDIHN, the development of Single Online Portal for Regulatory is in order to create a service of legal information that is reliable, can be accessed quickly, easily, complete and accurate, thereby supporting the fulfillment of rights human rights, namely the right to obtain legal information properly. So it can be a bridge for people on the fulfillment of the principle of fair legal fictie.

But in the management JDIH by utilizing information and communication technology (ICT), namely the management of the website of course there are some factors that become obstacles in its implementation, among others agency manager JDIH average shortage of competent human resources both in quantity and quality, especially in need of personnel competent in the field of ICT is because the average agency managers such as Legal Bureau at the Regional Secretariat of the Provincial Government or the Regional Secretariat's Legal Department in the District / City have personnel with a background in law, not master ICT personnel. But this can be overcome by proposing the addition of competent personnel in the field of ICT, if it has not been possible because of the limited power of ICT in these institutions, it could involve power of ICT in the Office of Communications and Information that could be used as the website administrator in Management Team website JDIH, besides improving the quality of existing human resources can be done by involving the Technical Assistance, Education and Training, Workshop related to the management JDIH with the use of ICT. Means and adequate infrastructure is also very supportive of the management of the website, the special room management JDIH, availability of

\footnotetext{
10 BPHN Kementerian Hukum dan HAM, 26 Juli 2018, "4 Jurus BPHN Percepat Integrasi Portal JDIHN", https://bphn.go.id/news/2018072610131253/4-Jurus-BPHN-Percepat-Integrasi-Portal-JDIHN, Accessed on 24 September 2018.
} 
hardware such as computers, printers, servers, scanners, and software applications is essential, internet access (wifi) is something that is absolutely available, all of which require a budget adequate support for the leadership of JDIH management is very important for improving the quality of management JDIH.

\section{Closing}

\subsection{Conclusion}

Legal Documentation and Information Network was instrumental to the fulfillment of human rights, namely the right to information law, especially information legislation. JDIH management by utilizing the Information Technology to make use of the website. legal information can be accessed quickly, easily, complete and accurate, thereby supporting the fulfillment of human rights, the right to obtain legal information properly. It is a bridge to the community for the fulfillment of the principle of fair legal fictie. In order to support the web-based management JDIH necessary competent human resources, the budget is sufficient, adequate infrastructure and leadership support.

\subsection{Suggestion}

Due Network Documentation and Information Law has an important role in the fulfillment of the right to information law, then the management should be implemented seriously, improving the quality of competent human resources can be done by involving the existing human resources in Technical Assistance, Education and Training, Meetings Center JDIHN and JDIHN members, or both workshops held important government and private sector, budget support, infrastructure and leadership support is essential for the improvement of the management of JDIH. It's good BPHN Ministry of Justice proposes Functional for business JDIH that management could be better.

\section{References}

[1] Agus Dwiyanto, 2003, Mewujudkan Good Governance Melayani Publik, Gadjah Mada University, Yogyakarta.

[2] Arif Budiman, 1982, Bentuk Negara dan Pemerataan Hasil-hasil Pembangunan, Prisma No.7,Jakarta

[3] Blasius Sudarsono, 2009, Pustakawan Cinta dan Teknologi, ISIPII, Jakarta.

[4] Harun Pudjiarto, 1999, Hak Asasi Manusia, Kajian Filosofis dan Implementasinya dalam Hukum Pidana Indonesia, Andi Offset, Yogyakarta.

[5] Nomensen Sinamo, 2005, Hukum Administrasi Negara, Jala Permata Aksara, Jakarta.

[6] Testiani Makmur,2015, Perpustakaan Era Keterbukaan Informasi Publik, Graha Ilmu, Yogyakarta.

[7] Constitution of the Republic of Indonesia of1945 and its amendment.

[8] Act No. 39 of 1999 on Human Rights.

[9] Act No. 14 of 2008 on Public Information. 
[10] Presidential Regulation No. 33 of 2012 on Information and Documentation Network national law.

[11] Regulation of the Minister of Law and Human Rights No. 02 of 2013 on the Standardization of Technical Management Documentation and Legal Information

[12] BPHN Kementerian Hukum dan HAM, 26 Juli 2018, "4 Jurus BPHN Percepat Integrasi Portal JDIHN", https://bphn.go.id/news/2018072610131253/4-JurusBPHN-Percepat-Integrasi-Portal-JDIHN, accessed date July 31, 2018.

[13] Karina Maharani, 10 Agustus 2010, "Pelaksanaan Sistem Informasi Manajemen Terpadu Di Biro Perencanaan Kantor Kementerian Negara Riset Dan Teknologi",http://elib.unikom.ac.id/gdl.php?mod=browse\&op=read\&id=jbptunik ompp-gdl-karinamaha $21144 \& q=$ sistem\%20pelayanan\%20informasiaccessed on 24 September 2018 